\title{
Persistent organic pollutants and their effects on Arctic seabirds
}

\author{
Geir Wing Gabrielsen \\ From Environmental contaminants and animal health. The 26th Symposium of the Nordic Committee for \\ Veterinary Scientific Cooperation (NKVet) \\ Helsinki, Finland. 6-7 October 2011
}

Persistent organic pollutants (POPs) and their degradation and metabolic byproducts have been found in high levels in blood and tissues of several Arctic seabird- and mammal species (Glaucous gull (Larus hyperboreus), Ivory gull (Pagophila eburnea), Great skua (Stercorarius skua), Arctic fox (Alopex lagopus) and Polar bear (Ursus maritimus). The POPs include both old (PCBs, DDTs and CHLs) and new contaminants (polybrominated diphenyl ethers (PBDEs), perfluorinated compounds (PFCs) and polychlorinated naphthalenes (PCNs). While the contaminants which are subjected to global bans or restrictions are decreasing, new and emerging chemicals are increasing in Arctic birds and mammals. Several species are also exposed to contaminant metabolites (p, p-DDE, OH- and MeSO2-PCBs and OH-PBDEs) that, at times, are more bioactive than their precursors. Of high concern are the potential effects of the POPs and their metabolites in exposed seabird species. The present presentation summarizes recent studies on biological effects in relation to POP exposure in seabirds.

Submit your next manuscript to BioMed Central and take full advantage of:

- Convenient online submission

- Thorough peer review

- No space constraints or color figure charges

- Immediate publication on acceptance

- Inclusion in PubMed, CAS, Scopus and Google Scholar

- Research which is freely available for redistribution

Norwegian Polar Institute, Fram Centre, NO-9296 Tromsø, Norway 